\title{
THE
}

\section{Habitat Correlates of Reproductive Effort in Wood Frogs and Spotted Salamanders in an Urbanizing Watershed}

\author{
Dennis E. Skidds \\ University of Rhode Island \\ Francis C. Golet \\ University of Rhode Island, fgolet@uri.edu \\ Peter W. C. Paton \\ University of Rhode Island, ppaton@uri.edu \\ Jonathan C. Mitchell
}

Follow this and additional works at: https://digitalcommons.uri.edu/nrs_facpubs

Terms of Use

All rights reserved under copyright.

\section{Citation/Publisher Attribution}

Skidds, D. E., Golet, F. C., Paton, P. W.C., \& Mitchell, J. C. (2007). Habitat Correlates of Reproductive Effort in Wood Frogs and Spotted Salamanders in an Urbanizing Watershed. J. of Herpetology, 41(3), 439-450. doi: 10.1670/0022-1511(2007)41[439:HCOREI]2.0.CO;2 Available at: http://dx.doi.org/10.1670/0022-1511(2007)41[439:HCOREI]2.0.CO;2

This Article is brought to you for free and open access by the Natural Resources Science at DigitalCommons@URI. It has been accepted for inclusion in Natural Resources Science Faculty Publications by an authorized administrator of DigitalCommons@URI. For more information, please contact digitalcommons-group@uri.edu. 


\section{BioOne COMPLETE}

\section{Habitat Correlates of Reproductive Effort in Wood Frogs and Spotted Salamanders in an Urbanizing Watershed}

Authors: Dennis E. Skidds, FRANCIS C. GOLET, Peter W. C. Paton, and Jonathan C. Mitchell

Source: Journal of Herpetology, 41(3) : 439-450

Published By: Society for the Study of Amphibians and Reptiles

URL: https://doi.org/10.1670/0022-1511(2007)41[439:HCOREI]2.0.CO;2

BioOne Complete (complete.BioOne.org) is a full-text database of 200 subscribed and open-access titles in the biological, ecological, and environmental sciences published by nonprofit societies, associations, museums, institutions, and presses.

Your use of this PDF, the BioOne Complete website, and all posted and associated content indicates your acceptance of BioOne's Terms of Use, available at www.bioone.org/terms-of-use.

Usage of BioOne Complete content is strictly limited to personal, educational, and non-commercial use. Commercial inquiries or rights and permissions requests should be directed to the individual publisher as copyright holder.

BioOne sees sustainable scholarly publishing as an inherently collaborative enterprise connecting authors, nonprofit publishers, academic institutions, research libraries, and research funders in the common goal of maximizing access to critical research. 


\title{
Habitat Correlates of Reproductive Effort in Wood Frogs and Spotted Salamanders in an Urbanizing Watershed
}

\author{
Dennis E. Skidds, ${ }^{1}$ Francis C. Golet, Peter W. C. Paton, and Jonathan C. Mitchell
}

Department of Natural Resources Science, University of Rhode Island, Kingston, Rhode Island 02881, USA

\begin{abstract}
АвsтRAст.-Wildlife biologists and managers are concerned about the effects of forest fragmentation and habitat loss on pond-breeding amphibian populations. Most research has assessed the effects of habitat composition at multiple spatial scales on the presence or absence of amphibians at breeding ponds. We were interested in the effects of habitat characteristics on amphibian population size and used Wood Frog (Rana sylvatica) and Spotted Salamander (Ambystoma maculatum) egg mass counts as an index. Between 2001 and 2005, we monitored 65 seasonal ponds within forested landscapes in the Pawcatuck River watershed of Rhode Island. Both species were detected in at least $88 \%$ of the ponds sampled. Egg mass counts for both species were highest in ponds that usually dried between early October and late November. Wood Frog egg mass numbers were positively associated with pond hydroperiod, size, and depth; location on glacial fluvial deposits; the extent of persistent nonwoody plant cover in ponds; and the area of upland forest within $1 \mathrm{~km}$ of the pond edge. Egg mass numbers were negatively associated with location on alluvium or dense till deposits, percent canopy cover, the number of buildings within $1 \mathrm{~km}$, and the area of residential development within $1 \mathrm{~km}$. Spotted Salamander egg mass counts were positively associated with pond hydroperiod, size, and depth, and upland forest area within $1 \mathrm{~km}$. They were negatively related to location on alluvium. Multivariate models developed from within-pond variables explained more variation in egg mass counts for both species than those developed from landscape-level factors, but the best combined models suggested that habitat characteristics at both scales are useful in the prediction of breeding effort at individual sites. Given the continuing urbanization of southern New England and the ineffectiveness of wetland regulations in protecting required terrestrial habitat around seasonal ponds, proactive techniques also are required to assure the maintenance of pond-breeding amphibian populations.
\end{abstract}

Wildlife biologists and managers are increasingly concerned about the potential negative impacts of forest fragmentation and habitat loss on pond-breeding amphibian populations. Most research and wetland regulations promulgated to date have focused on breeding ponds and the habitats immediately surrounding them. Key breeding pond characteristics affecting amphibian community composition include hydroperiod (Babbitt and Tanner, 2000; Snodgrass et al., 2000; Egan and Paton, 2004), vegetation structure (Seale, 1982; Formanowicz and Bobka, 1989), and tree canopy cover (Skelly et al., 2002; Skelly and Golon, 2003).

Research has also addressed the effects of landscape composition and configuration on pond-breeding amphibians because most species have complex life cycles that require terrestrial as well as aquatic habitats (Wilbur, 1980; Sinsch, 1992; Sjogren-Gulve, 1994). The primary focus of these studies has been the association between the presence of pondbreeding amphibians and certain landscape characteristics (Koloszvary and Swihart, 1999; Guerry and Hunter, 2002; Porej et al., 2004).

\footnotetext{
${ }^{1}$ Corresponding Author. E-mail: Dennis_Skidds@ nps.gov
}

Many species of pond-breeding amphibians are positively associated with the amount of forest within 200 to $1000 \mathrm{~m}$ of breeding ponds (Porej et al. 2004; Homan et al., 2004; Hermann et al., 2005). In addition, an accumulating body of literature has shown that, for species associated with forested habitats during the terrestrial phase of their annual cycle, habitat alterations of forested uplands can result in greater landscape resistance, which reduces dispersal capabilities of many species (deMaynadier and Hunter, 1998; Gibbs, 1998; Guerry and Hunter, 2002; Rothermel and Semlitsch, 2002).

Despite the increasing evidence that landscape-level habitat characteristics influence amphibian community composition, few researchers have conducted empirical studies investigating amphibian population sizes in heterogeneous, human-dominated landscapes across a wide geographic range (Laan and Verboom, 1990; Vos and Chardon, 1998; Lehtinen et al., 1999; Homan et al., 2004). For example, little is known about the impact of urban sprawl on pond-breeding amphibian populations in forested landscapes (Gibbs, 2000; Marsh and Trenham, 2001).

Our primary objective was to investigate the relationship between an index of annual breed- 
ing effort (egg mass counts) for two species of pond-breeding amphibians, Wood Frogs (Rana sylvatica) and Spotted Salamanders (Ambystoma maculatum), and both within-pond and landscape-level habitat characteristics. Wood Frogs and Spotted Salamanders deposit large, globular egg masses that are relatively easy to survey compared to other amphibian species in the northeastern United States. Egg masses of both species are persistent, remaining evident for 3-4 weeks from initial egg deposition to hatching (Klemens, 1993; Crouch and Paton, 2000) and for two months or more after hatching in the case of Spotted Salamanders (FCG, pers. obs.). Thus, egg mass counts are an efficient and accurate technique for quantifying the breeding effort of both species within a given year (Crouch and Paton, 2000; Egan and Paton, 2004).

We developed a number of multivariate regression models using within-pond and landscape-scale habitat characteristics to account for the variation observed in Wood Frog and Spotted Salamander egg mass counts at 65 seasonal forest ponds in the Pawcatuck River watershed of southern Rhode Island. These models were subsequently evaluated using an information-theoretic model selection framework (Burnham and Anderson, 2002). Such models can be used to identify key factors that influence the abundance of amphibians and could be used by state and federal regulators, municipal conservation commissions, land trusts, and environmental consultants to identify specific areas of high amphibian abundance for conservation.

\section{Materials and Methods}

Study Area.-We conducted our study in a 51,000-ha area of the Pawcatuck River watershed in southern Rhode Island (Fig. 1). The landscapes of Rhode Island are representative of those occurring throughout southern New England, having formed primarily in Pleistocene-aged glacial deposits (Schafer and Hartshorn, 1965; Quinn, 1973). These landscapes have a surficial geology that consists primarily of loose ablation till, dense lodgment till, and stratified glacial fluvial deposits. Postglacial alluvium forms narrow bands along streams in lower areas of the landscape. The Pawcatuck watershed is located just north of the southern limit of the Laurentide ice sheet during the Wisconsin glaciation and is marked by an abundance of glacial kettles and other shallow depressions (Flint, 1971), many of which support populations of pond-breeding amphibians. As of 1995, 57\% of the study area was covered by upland forest, $16 \%$ was wetland, and 15\% had been developed for residen- tial or commercial purposes; agricultural land covered $8 \%$ of the study area (data from the Rhode Island Geographic Information System [RIGIS]: August et al., 1995).

Study Site Selection.-To identify potential study sites, we used a survey of 1039 potential breeding ponds identified by the Rhode Island Chapter of The Nature Conservancy (unpubl. data) through interpretation of 1995 1: 12,000scale panchromatic aerial photographs. We limited the target data set to potential breeding ponds that were not associated with permanent open water bodies, because they might contain fish, and to ponds that had some adjacent forest that could provide terrestrial habitat for the pond-breeding amphibians of interest (Calhoun and Klemens, 2002). Using RIGIS land use data (August et al., 1995), we identified 471 potential breeding ponds that (1) were not contiguous with perennial streams or lakes, (2) were $<0.8$ ha in size and, therefore, unlikely to be permanently inundated, (3) were bordered by upland forest along at least $50 \%$ of their perimeter, and (4) had at least 50\% upland forest cover within $300 \mathrm{~m}$ of the pond edge.

To obtain a sample of ponds representative of the variety of geologic settings and pond sizes found in the watershed, we employed a stratified random sampling design. We overlaid the potential ponds coverage on a surficial geology (soil parent material) data set developed by Rosenblatt (2000) from the Rhode Island Soil Survey (Rector, 1981) and classified each pond as occurring on loose till, dense till, glacial fluvial deposits, or alluvium. After inspecting the size distribution of these 471 ponds, we divided the sites into four size categories $(<0.02$ ha, $0.02-0.04$ ha, $0.05-0.124$ ha, and $0.125-0.8 \mathrm{ha})$. We entered all ponds into a matrix consisting of the four size categories and the four surficial geologic types, chose ponds randomly from each cell in the matrix, and contacted landowners for permission to access the sites. We repeated the process until a sample of 65 ponds with access was obtained.

Within-Pond Field Data Collection.-We quantified 11 potential, within-pond, independent variables (Table 1). We defined hydroperiod as the number of weeks of continuous surface inundation beginning on 1 March of each year, which is the approximate start of the breeding season for Wood Frogs and Spotted Salamanders in southern Rhode Island in most years (Paton and Crouch, 2002). From 2001 to 2004 we measured, every two weeks, the distance between a fixed reference point outside of the pond and the edge of standing water along a fixed compass bearing and noted the date when the pond dried. Ponds still inundated on 


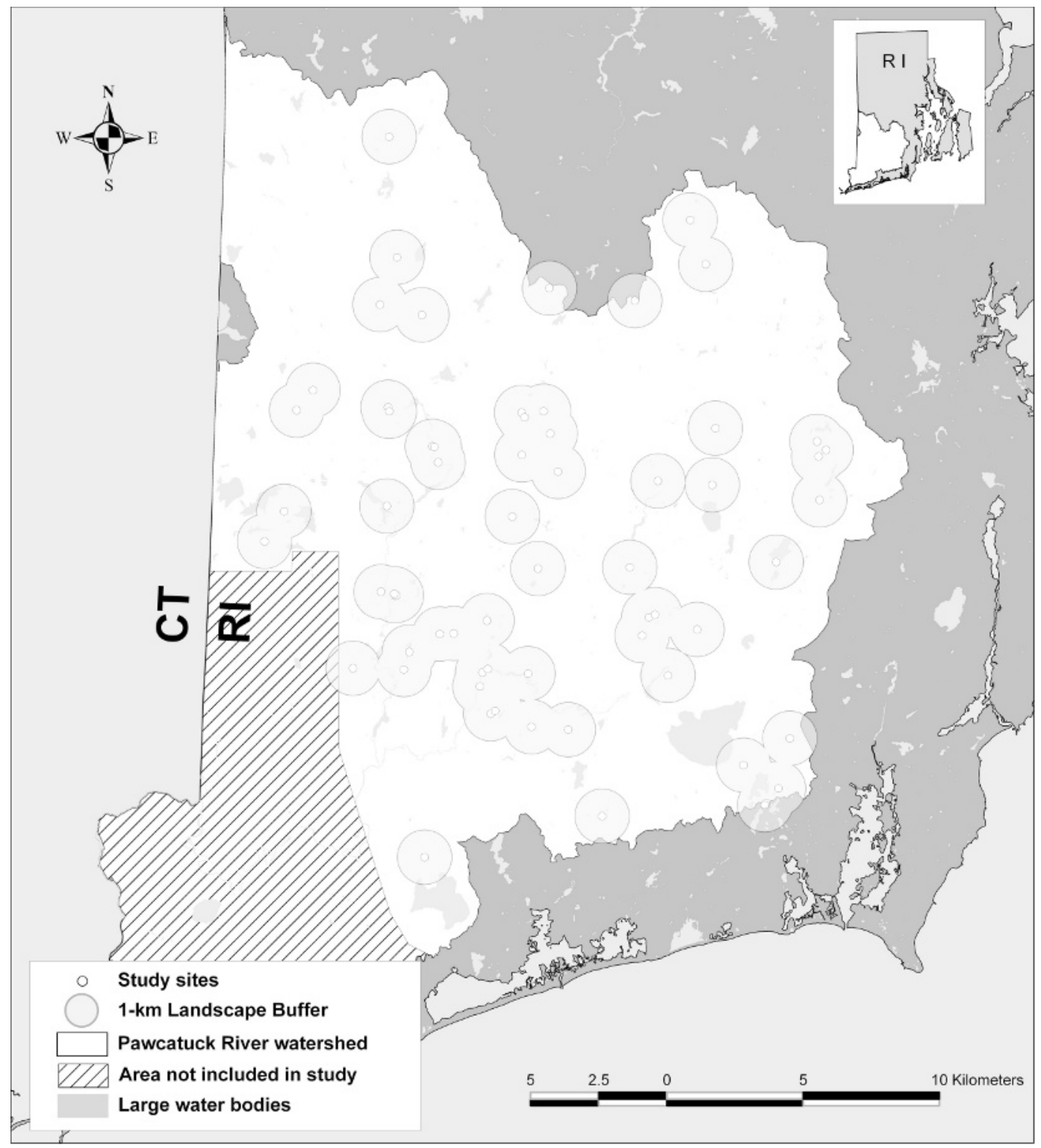

FIG. 1. Distribution of 65 seasonal pond study sites within the Pawcatuck River watershed of southern Rhode Island.

31 December were assigned a hydroperiod of 44 weeks.

During the fall of 2001-2003, we used a Topcon AT-G6 autolevel and height rod to determine the elevation of surface water on each of the measurement dates relative to the deepest point in the pond. We used these data to construct hydrographs depicting basin elevational profiles and water levels at each pond throughout the year. We obtained maximum pond-depth measurements by subtracting the elevation of the lowest point in the pond basin from the elevation of the highest standing water level on or after 1 March of each year. Because annual maximum pond depth often fluctuates markedly among years, we created another variable, termed "open basin depth," for each pond by subtracting the elevation of the lowest point in the basin from the elevation of the soil surface at the pondward limit of tree stems. The absence of trees pondward of this point was inferred to be caused by annual hydroperiods that, on average, exceeded the tolerance level of the trees. Thus, open basin depth had the 
TABLE 1. Descriptive statistics for within-pond and landscape-level characteristics for 65 ponds in the Pawcatuck River watershed, Rhode Island.

\begin{tabular}{|c|c|c|c|c|}
\hline Variable & Units & Code & Mean $\pm \mathrm{SE}$ & Range \\
\hline \multicolumn{5}{|l|}{ Within-pond } \\
\hline Hydroperiod (mean of 2001-2004) & weeks & Hydroperiod & $29.2 \pm 1.03$ & $13.5-44.0$ \\
\hline Max. water depth (mean of 2001-2003) & $\mathrm{m}$ & Pond depth & $0.95 \pm 0.06$ & $0.3-2.3$ \\
\hline Open basin depth & $\mathrm{m}$ & Open basin & $1.01 \pm 0.09$ & $0.16-3.75$ \\
\hline Pond size & ha & Pond size & $0.11 \pm 0.02$ & $0.004-0.61$ \\
\hline Alluvium & $\mathrm{NA}^{\mathrm{a}}$ & Alluvial & NA & NA \\
\hline Dense till & NA & Dense & NA & NA \\
\hline Glacial fluvial & NA & GF & NA & NA \\
\hline Loose till & NA & Loose & NA & NA \\
\hline Canopy cover & $\%$ & Canopy & $68.0 \pm 3.3$ & $12-100$ \\
\hline Persistent non-woody plant cover & $\%$ & $\begin{array}{l}\text { Persistent } \\
\text { nonwoody }\end{array}$ & $14.9 \pm 2.1$ & $0.0-53.5$ \\
\hline Shrub cover & $\%$ & Shrub & $24.8 \pm 2.3$ & $0.8-84.1$ \\
\hline \multicolumn{5}{|c|}{ Landscape (measured within $1 \mathrm{~km}$ of breeding ponds) } \\
\hline Area of residential development & $\mathrm{km}^{2}$ & Residential & $0.29 \pm 0.03$ & $0-0.91$ \\
\hline Area of wetland & $\mathrm{km}^{2}$ & Wetland & $0.57 \pm 0.04$ & $0.2-1.6$ \\
\hline Area of upland & $\mathrm{km}^{2}$ & Upland & $2.57 \pm 0.04$ & $1.5-3.0$ \\
\hline Area of wetland forest & $\mathrm{km}^{2}$ & Wetland forest & $0.39 \pm 0.03$ & $0.06-1.27$ \\
\hline Area of upland forest & $\mathrm{km}^{2}$ & Upland forest & $1.90 \pm 0.07$ & $0.63-2.90$ \\
\hline Length of paved roads & $\mathrm{km}$ & Road length & $5.31 \pm 0.41$ & $0.0-19.3$ \\
\hline Area of paved roads & $\mathrm{km}^{2}$ & Road area & $37.7 \pm 2.9$ & $0.0-130.1$ \\
\hline Number of buildings & count & Buildings & $62.5 \pm 7.4$ & $0-233$ \\
\hline
\end{tabular}

${ }^{\text {a } N A, ~ n o t ~ a p p l i c a b l e . ~}$

potential to be a meaningful indicator of maximum annual pond depth over the long term.

Initially, we assessed pond size using ARCINFO 3.5.1 GIS software (Environmental Systems Research Institute, Redlands, CA, 1997) and the GIS ponds coverage described above. Field observations indicated that size estimates using this technique often were inaccurate, particularly for ponds $<0.05$ ha. For that reason, we recalculated pond areas through a combination of field measurements and GIS techniques. First, we obtained measurements of the distances between eight standard points on three vegetation sampling transects spanning each pond (the ends of each transect and the intersections between transects). Then we used the locations of these eight points to interpolate an ARCINFO polygon coverage from which we could obtain area measurements. Detailed field measurements of several small ponds confirmed that area estimates derived in this manner were more accurate than area calculations from the original GIS coverage.

We field-checked the surficial geology classification of each pond with a soil auger and reclassified several ponds as a result of mapping errors or inclusions that were too small for the soil survey (Rector, 1981) to depict.

We sampled the vegetation of each pond using the line-intercept method (Canfield, 1941) along three transects during mid- to late summer in 2001 and 2002. We established the first transect along the long axis of the pond or along a north-south bearing in circular ponds, extending from high-water mark to high-water mark. High-water marks were located using indicators such as watermarks on trees or the pondward limit of common upland plants such as the clubmoss, Lycopodium obscurum [L.], or the sedge, Carex pensylvanica [Lam.]. We established two additional transects at right angles to the first, one-third and two-thirds of the way along its length. We recorded the length of each transect intercepted by persistent nonwoody plants (i.e., emergent herbaceous and graminaceous plants that were evident throughout the year), as well as shrubs (i.e., woody plants $<6 \mathrm{~m}$ tall). We calculated the canopy cover of woody plants at least $3 \mathrm{~m}$ in height in 2001 based on GRS densitometer assessments of foliage occurrence at $1-\mathrm{m}$ intervals along each vegetation transect. Values were converted to a percentage of the whole pond.

Landscape Data Collection.-We quantified eight potential, landscape-scale, independent variables (Table 1) using land use and wetland data obtained from the RIGIS database (August et al., 1995), and 1:5000 scale digital orthophotographs taken in 1997. RIGIS wetland boundaries were interpreted from 1988 aerial photographs (scale $=1: 24,000)$ and digitized using 0.1-ha minimum mapping units. The land use database was created from 1995 aerial photographs and was built around the wetland database using 0.2-ha minimum mapping units 
(August et al., 1995). Recent studies investigating multiple spatial scales have found that characterization of landscapes within $1 \mathrm{~km}$ of breeding ponds yielded the best models for predicting species occurrence (Pope et al., 2000; Guerry and Hunter, 2002; Homan et al. 2004). Therefore, we assessed all landscape variables within a $1-\mathrm{km}$ buffer. We heads-up digitized the centerline of all paved roads using 1:5000 digital orthophotographs taken in 1997 and then buffered this feature by one-half the measured road width to calculate total paved road area. We digitized all buildings (i.e., houses, barns, and commercial structures) within $1 \mathrm{~km}$ of each pond, also using the 1997 orthophotographs.

Amphibian Annual Reproductive Effort.-We counted egg masses of Wood Frogs and Spotted Salamanders at 62 ponds in 2001, 65 ponds in 2002 and 2003, and 63 ponds in 2004 and 2005. Each individual female Wood Frog deposits one egg mass at a communal deposition site within a pond (Crouch and Paton, 2000). This 1:1 egg mass-to-adult female ratio provides an accurate index of annual breeding population effort. The relationship between the number of egg masses and number of breeding females for Spotted Salamanders has not been accurately determined but appears to range from one to four egg masses per female (Petranka, 1998). In each year, we conducted two egg mass surveys at each pond between 15 March and 25 April, which is the peak oviposition period in Rhode Island (Egan and Paton, 2004).

Statistical Analyses.-Using Spearman-rank correlation analysis, we assessed relationships between egg mass counts (maximum count among the five years) and all within-pond and landscape-level variables, and examined relationships among the independent variables. We used multiple linear regression, with egg mass counts as the response variable and withinpond and landscape-level habitat characteristics as independent variables, to explain relative Wood Frog and Spotted Salamander breeding effort. We first developed a set of candidate models that included only within-pond variables. We used a maximum of nine independent variables in each regression to retain a ratio of sampling units to independent variables of at least 7:1. The nine independent variables included 4-yr mean hydroperiod; pond size; open basin depth; whether or not the pond occurred on alluvium, dense till, loose till, or glacial fluvial geologic deposits; percent persistent nonwoody plant cover; and percent shrub cover. These variables were chosen based upon a priori knowledge of habitat associations of Wood Frogs and Spotted Salamanders (Klemens, 1993; Gibbs, 1998; deMaynadier and
Hunter, 1999; Egan and Paton, 2004), ease of measurement, and low collinearity (Spearmanrank correlation coefficient $\left.r_{s}<0.60\right)$. Egg mass counts were $\log _{10}$-transformed to improve homogeneity of variances and achieve normality.

We used an information-theoretic approach to select the most parsimonious model (Burnham and Anderson, 2002). Akaike's Information Criterion adjusted for small samples $\left(\mathrm{AIC}_{\mathrm{c}}\right.$ ) was used to compare possible regression models based on a priori hypotheses. Because these analyses were somewhat exploratory, we compared a large number of models (50 each for Spotted Salamanders and Wood Frogs). AIC $\mathrm{C}_{\mathrm{c}}$ values were rescaled to provide an estimate $\left(\Delta_{i}\right)$ of the plausibility that a given model was the optimal one, and Akaike weights $\left(w_{i}\right)$ were used to calculate the probability that a given model minimized the amount of information that was lost.

In an analogous manner, we constructed multiple linear regression models using landscape-level characteristics as independent variables. We selected three potential variables, including the total areas of residential development, upland forest, and wetland forest within $1 \mathrm{~km}$ of the pond (Table 1). As in the previous analysis, we used $\mathrm{AIC}_{\mathrm{c}}$ to select the most parsimonious model. A final set of regression models was constructed using the most powerful variables (i.e., variables occurring frequently in the most highly ranked models) from both the within-pond and landscape-level candidate model sets. We compared 50 models for Spotted Salamanders and 60 for Wood Frogs.

We used Kolmogorov-Smirnov goodness-offit tests to determine whether the residuals of the final models were normally distributed and examined the first and second moments to determine whether the model had been correctly specified and whether there was any evidence of heteroscedasticity. We used Moran's I analyses in GS+ (vers. 5.3.1, Gamma Design Software, Plainwell, MI, 2002) to determine whether independent variables in the model were spatially autocorrelated. Within-pond variables were not spatially autocorrelated at most distances. Although there was overlap among ponds at the landscape scale (Fig. 1), there were few significant $(P<0.05)$ spatially autocorrelated points among landscape variables. The few cases of autocorrelation for some variables at specific distances were considered minor because (1) the residuals of the final model were not spatially correlated, and (2) the increased probability of a Type I error rate, which may result from significant autocorrelation, is acceptable for aggressive conservation 
efforts (i.e., greater power for detecting differences; Underwood, 1997).

All statistical analyses were performed using SPSS 8.0.0 software (SPSS, Inc., Chicago, IL, 1997) and SAS 8.0e software (SAS Institute, Inc., Cary, NC, 2000). Unless otherwise noted, all descriptive statistics include $\bar{x} \pm \mathrm{SE}$, and we accepted statistical significance at $P \leq 0.05$.

\section{RESULTS}

Within-Pond Characteristics.-Ponds ranged in size from $0.004-0.61 \mathrm{ha}$, with a mean of $0.11 \pm$ 0.02 ha (Table 1). Maximum water depth averaged $1.12 \pm 0.08 \mathrm{~m}$ in 2001, $0.73 \pm 0.06 \mathrm{~m}$ in 2002, and $1.02 \pm 0.06 \mathrm{~m}$ in 2003; mean open basin depth was $1.01 \pm 0.09 \mathrm{~m}$. The overall mean hydroperiod for 2001-2004 was $29.2 \pm$ 1.03 weeks after 1 March; however, there was considerable annual variation. The mean hydroperiod for ponds in 2001 was $29.3 \pm 1.14$ weeks, with ponds that dried having hydroperiods that ranged from nine weeks to 38 weeks, and 14 ponds remaining inundated throughout the year (i.e., the hydroperiod was 44 weeks). In 2002, a relatively dry year, only three ponds remained inundated throughout the year, and the mean hydroperiod was $19.9 \pm 0.92$ weeks; hydroperiods of drying ponds ranged from two to 24 weeks. In 2003, a relatively wet year, the mean hydroperiod was $36.4 \pm 1.24$ weeks with a range from 18 weeks to 31 weeks for ponds that dried and 39 ponds holding water through the year. The mean hydroperiod in 2004 was $31.0 \pm 1.62$ weeks; 30 ponds remained inundated through 31 December, and the remaining ponds' hydroperiods ranged from 14 to 29 weeks.

Canopy cover ranged from $<20 \%$ in two ponds to $100 \%$ in 15 ponds, with a mean of 68.0 $\pm 3.3 \%$. Canopy cover was negatively correlated with mean hydroperiod $\left(r_{s}=-0.42, P<\right.$ $0.001)$, mean maximum water depth $\left(r_{s}=-0.26\right.$, $P<0.05)$, open basin depth $\left(r_{s}=-0.33, P<\right.$ $0.01)$, and pond size $\left(r_{s}=-0.70, P<0.0001\right)$. Persistent non-woody plant cover ranged from 0 to $54 \%$, with a mean of $14.9 \pm 2.1 \%$; shrub cover ranged from 1 to $84 \%$ with a mean of $24.8 \pm 2.3 \%$ (Table 1 ).

Landscape-Scale Characteristics.-Even though we initially selected ponds based on a minimum amount $(\geq 50 \%)$ of adjacent upland forest within $300 \mathrm{~m}$ of breeding ponds, the characteristics of the landscapes within $1 \mathrm{~km}$ of the ponds ranged considerably (Table 1). The area of residential development within $1 \mathrm{~km}$ ranged from $0-0.91 \mathrm{~km}^{2}$, with a mean of $0.29 \pm$ $0.03 \mathrm{~km}^{2}$. The mean number of buildings within $1 \mathrm{~km}$ was $62.5 \pm 7.4$, with a range of $0-233$. Area of wetland forest ranged from $0.06-1.27 \mathrm{~km}^{2}(\bar{x}$ $\left.=0.39 \pm 0.03 \mathrm{~km}^{2}\right)$, whereas area of upland forest ranged from $0.63-2.90 \mathrm{~km}^{2}(\bar{x}=1.90 \pm$ $0.07 \mathrm{~km}^{2}$. The mean area of paved roads was $37.7 \pm 2.9 \mathrm{~km}^{2}$, with a range of 0.0 $130.1 \mathrm{~km}^{2}$.

Egg Mass Counts.-We detected Wood Frog egg masses in $91 \%$ of the ponds in at least one of five years. Likewise, we counted Spotted Salamander egg masses in $88 \%$ of the ponds. There was a positive relationship between the maximum egg mass counts of Wood Frogs and Spotted Salamanders $(r=0.66, P<0.001)$. Wood Frogs were more abundant than Spotted Salamanders, with maximum annual egg mass counts per pond for the five years averaging $457.7 \pm 90.1$ (range $=0-3764$ ). Six ponds contained no egg masses in any year and $42 \%$ of the ponds contained peak numbers of $<100$ egg masses. In contrast, Spotted Salamander maximum egg mass counts per pond for the five years averaged $69.9 \pm 15.3$ (range $=0-672$ ), with eight ponds containing no egg masses and $78 \%$ of the ponds containing peaks of $<100$ egg masses.

Egg Mass-Habitat Relationships.-Among the within-pond parameters that we assessed, Wood Frog egg mass counts were positively associated with hydroperiod $\left(r_{s}=0.25, P=\right.$ $0.04)$, pond size $\left(r_{s}=0.58, P<0.0001\right.$; Fig. 2$)$, open basin depth $\left(r_{s}=0.42, P<0.001\right)$, location on glacial fluvial material $\left(r_{s}=0.34, P=0.01\right)$, and persistent nonwoody plant cover $\left(r_{s}=0.30\right.$ $P=0.02$; Fig. 2); negatively associated with canopy cover $\left(r_{s}=-0.46, P=0.001\right)$ and location on alluvial material $\left(r_{s}=-0.45, P=\right.$ $0.001)$ or dense till $\left(r_{s}=-0.29, P=0.02\right)$; and not associated with shrub cover $\left(r_{s}=0.15, P=\right.$ $0.24)$, or location on loose till $\left(r_{s}=0.21, P=\right.$ 0.09 ).

Spotted Salamander egg mass counts exhibited no association with percent tree canopy cover $\left(r_{s}=-0.16, P=0.20\right)$, shrub cover $\left(r_{s}=\right.$ $0.17, P=0.18)$, persistent nonwoody plant cover $\left(r_{s}=-0.02, P=0.90\right)$, or location on loose till $\left(r_{s}\right.$ $=0.25, P=0.05)$, dense till $\left(r_{s}=0.01, P=0.95\right)$ or glacial fluvial material $\left(r_{s}=0.16, P=0.20\right)$. Spotted Salamander egg mass counts exhibited a positive relationship with hydroperiod $\left(r_{s}=\right.$ $0.31, P=0.01$; Fig. 3$)$, pond size $\left(r_{s}=0.26, P=\right.$ $0.03)$, and open basin depth $\left(r_{s}=0.35, P=0.01\right)$ and a negative relationship with location on alluvial material $\left(r_{s}=-0.49, P<0.0001\right)$.

Among the landscape-scale parameters that we assessed, Wood Frog egg mass counts were positively associated with upland forest $\left(r_{s}=\right.$ $0.30, P=0.02$; Fig. 3 ), negatively correlated with the extent of residential development $\left(r_{s}=\right.$ $-0.32, P=0.01$ ) and the number of buildings within $1 \mathrm{~km}\left(r_{s}=-0.32, P=0.01\right)$, and not associated with wetland forest $\left(r_{s}=0.05, P=\right.$ 
A.

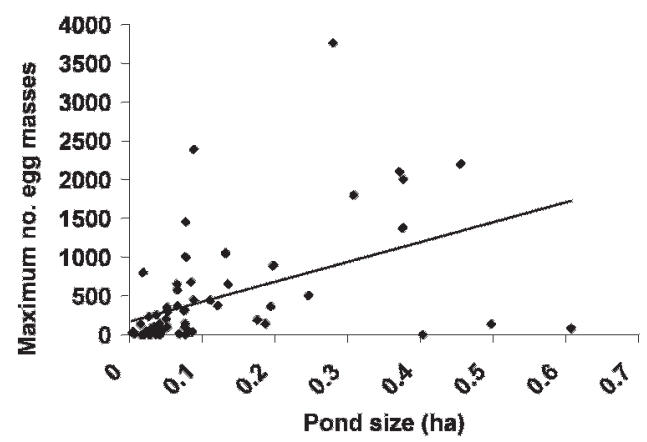

$\mathrm{B}_{*}$

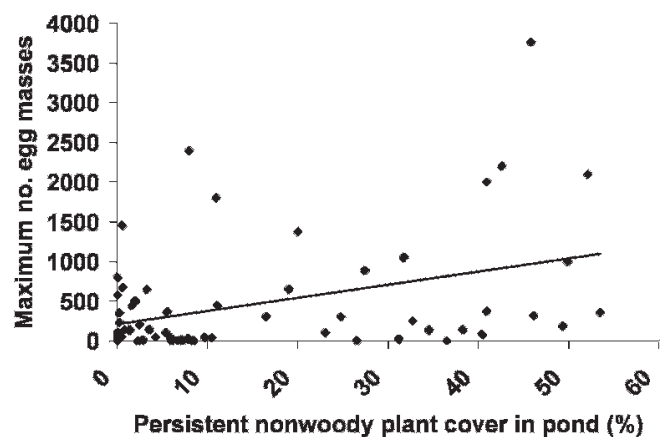

C.n

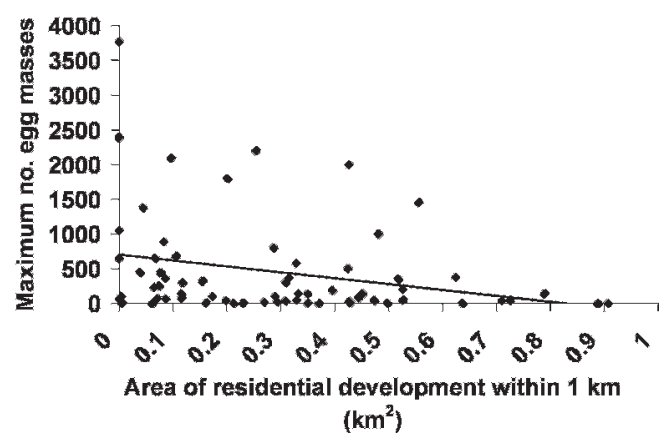

FIG. 2. Relationship between individual, continuous habitat variables included in the best multivariate models and maximum Wood Frog egg mass numbers observed in 65 seasonal ponds in Rhode Island between 2001 and 2005. (A) Pond size; (B) Persistent non-woody plant cover; (C) Area of residential development within $1 \mathrm{~km}$.

0.70). Spotted Salamander egg mass counts were positively associated with the area of upland forest $\left(r_{s}=0.26, P=0.04\right)$ but unrelated to the extent of residential development $\left(r_{s}=\right.$ $-0.21, P=0.10)$, number of buildings within $1 \mathrm{~km}\left(r_{s}=-0.22, P=0.08\right)$, or the area of wetland forest $\left(r_{s}=0.05, P=0.72\right)$.

Multivariate Regression Models.-Within-pond characteristics explained more of the variation in egg mass counts for Wood Frogs (Adj. $r^{2}=$
A.

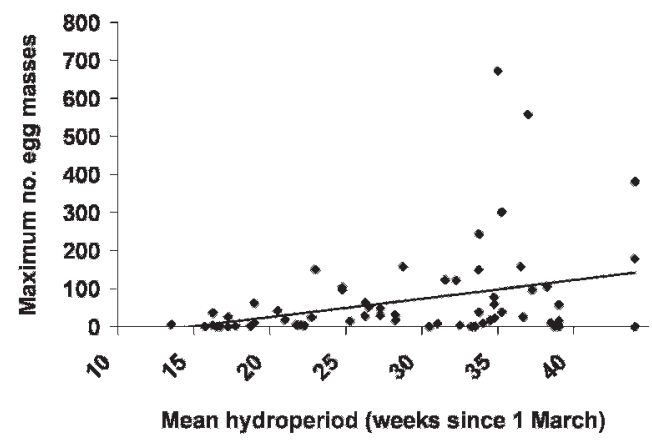

B.

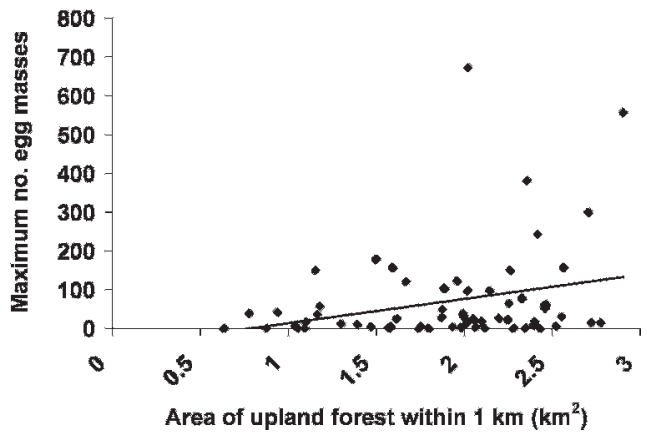

FIG. 3. Relationship between individual, continuous habitat variables included in the best multivariate models and maximum Spotted Salamander egg mass numbers observed in 65 seasonal ponds in Rhode Island between 2001 and 2005. (A) Mean hydroperiod; (B) Area of upland forest within $1 \mathrm{~km}$.

0.34) than for Spotted Salamanders (Adj. $r^{2}=$ 0.25; Tables 2 and 3). Landscape-scale characteristics explained roughly the same amount of variation for both species (Adj. $r^{2}=0.09$ for Wood Frogs; Adj. $r^{2}=0.07$ for Spotted Salamanders). The best models that included both within-pond and landscape-scale characteristics explained slightly more of the variation in egg mass counts than the best models based on within-pond characteristics alone (Tables 2 and 3). Variables included in the best Wood Frog combined model (Adj. $r^{2}=0.37$ ) were pond size, the amount of residential development within $1 \mathrm{~km}$ of a breeding pond, the extent of persistent non-woody plant cover within the pond (Fig. 2), and whether the pond was located on alluvium, loose till, or glacial fluvial geologic deposits (Table 2). Variables included in the best Spotted Salamander combined model (Adj. $r^{2}=0.27$ ) were the amount of upland forest within $1 \mathrm{~km}$ of a breeding pond, mean hydroperiod, and whether the pond was located on alluvium (Table 3). 
TABLE 2. Ranking of the top five multivariate regression models explaining the relationships between Wood Frog egg mass counts and within-pond, landscape, and both within-pond and landscape characteristics. See Table 1 for explanation of terms.

\begin{tabular}{|c|c|c|c|}
\hline & Adj. $\mathrm{r}^{2}$ & $\Delta_{\mathrm{i}}^{\mathrm{a}}$ & $w_{\mathrm{i}}^{\mathrm{b}}$ \\
\hline \multicolumn{4}{|l|}{ Within-pond only } \\
\hline Pond size + persistent nonwoody + alluvial $+\mathrm{GF}+$ loose & 0.34 & 0.00 & 0.13 \\
\hline Pond depth + persistent nonwoody + alluvial + GF + loose & 0.33 & 0.37 & 0.11 \\
\hline Pond size + alluvial + GF + loose & 0.32 & 0.58 & 0.10 \\
\hline Pond size + persistent nonwoody + alluvial + GF + loose + shrub & 0.34 & 1.11 & 0.08 \\
\hline Alluvial + GF + loose & 0.30 & 1.25 & 0.07 \\
\hline \multicolumn{4}{|l|}{ Landscape only } \\
\hline Residential & 0.09 & 0.00 & 0.32 \\
\hline Upland forest + residential & 0.10 & 0.35 & 0.27 \\
\hline Wetland forest + residential & 0.09 & 1.34 & 0.16 \\
\hline Upland forest + wetland forest + residential & 0.09 & 2.55 & 0.09 \\
\hline Upland forest & 0.05 & 2.71 & 0.08 \\
\hline \multicolumn{4}{|l|}{ Within-pond and landscape } \\
\hline Residential + pond size + persistent nonwoody + alluvial + GF + loose & 0.37 & 0.00 & 0.17 \\
\hline $\begin{array}{l}\text { Residential }+ \text { pond size }+ \text { persistent nonwoody }+ \text { alluvial }+ \text { GF }+ \text { loose } \\
+ \text { upland forest }\end{array}$ & 0.37 & 1.28 & 0.09 \\
\hline Pond size + persistent nonwoody + alluvial + GF + loose & 0.34 & 1.58 & 0.08 \\
\hline $\begin{array}{l}\text { Pond size }+ \text { persistent nonwoody }+ \text { alluvial }+ \text { GF }+ \text { loose }+ \text { wetland forest } \\
+ \text { upland forest }\end{array}$ & 0.43 & 1.62 & 0.08 \\
\hline Pond size + alluvial + GF + loose & 0.36 & 2.16 & 0.06 \\
\hline
\end{tabular}

${ }^{\text {a }}$ Difference in Akaike Information Criterion score between the $\mathrm{i}^{\text {th }}$ and top-ranked model.

${ }^{b}$ Akaike weight, which represents the likelihood of a model being the best model in a candidate set of models.

\section{DisCUSSION}

Our study underscores the importance of quantifying habitat features both within breeding ponds and at the landscape scale when attempting to estimate the population size of
Wood Frogs and Spotted Salamanders. Withinpond features explained much of the variation in egg mass counts for both species, but models including characteristics from both spatial scales explained more variation in reproductive

TABLE 3. Ranking of the top five multivariate regression models explaining the relationships between Spotted Salamander egg mass counts and within-pond, landscape, and both within-pond and landscape characteristics. See Table 1 for explanation of terms.

\begin{tabular}{|c|c|c|c|}
\hline Model & Adj. $r^{2}$ & $\Delta_{\mathrm{i}}^{\mathrm{a}}$ & $w_{\mathrm{i}}^{\mathrm{b}}$ \\
\hline \multicolumn{4}{|l|}{ Within-pond only } \\
\hline Alluvial + hydroperiod & 0.25 & 0.00 & 0.15 \\
\hline Alluvial + shrub + hydroperiod & 0.25 & 0.53 & 0.11 \\
\hline Alluvial & 0.23 & 0.60 & 0.11 \\
\hline Alluvial + hydroperiod + persistent nonwoody & 0.23 & 2.14 & 0.05 \\
\hline Alluvial + shrub & 0.22 & 2.17 & 0.05 \\
\hline \multicolumn{4}{|l|}{ Landscape only } \\
\hline Upland forest & 0.07 & 0.00 & 0.30 \\
\hline Upland forest + residential & 0.08 & 0.81 & 0.20 \\
\hline Residential + wetland forest & 0.07 & 1.12 & 0.17 \\
\hline Upland forest + wetland forest & 0.06 & 2.12 & 0.11 \\
\hline Residential & 0.04 & 2.23 & 0.10 \\
\hline \multicolumn{4}{|l|}{ Within pond and landscape } \\
\hline Hydroperiod + alluvial + upland forest & 0.27 & 0.00 & 0.14 \\
\hline Hydroperiod + alluvial + upland forest + shrub & 0.28 & 0.94 & 0.09 \\
\hline Alluvial + hydroperiod & 0.25 & 1.36 & 0.07 \\
\hline Hydroperiod + alluvial + shrub & 0.25 & 1.88 & 0.06 \\
\hline Alluvial & 0.23 & 1.95 & 0.05 \\
\hline
\end{tabular}

${ }^{\text {a }}$ Difference in Akaike Information Criterion score between the $\mathrm{i}^{\text {th }}$ and top-ranked model.

${ }^{b}$ Akaike weight, which represents the likelihood of a model being the best model in a candidate set of models. 
effort than models based on within-pond features alone. Generally, models composed solely of within-pond characteristics accounted for more variation in Wood Frog egg mass counts then Spotted Salamander counts.

Hydroperiod was one of the most informative within-pond characteristics for predicting breeding effort. Previous research in southern Rhode Island (Paton and Crouch, 2002) demonstrated that $95 \%$ of Wood Frog metamorphs have emigrated from breeding ponds by late July, whereas barely $50 \%$ of Spotted Salamander metamorphs have emigrated by mid-August; egg-laying occurs at approximately the same time. Despite this difference in minimum hydroperiod requirements, we found that egg mass counts for both species were highest in ponds that dried after mid-October. We suggest that high reproductive effort by both species in normally long-hydroperiod, nonpermanent ponds may increase population stability over the long term because of the reduced chances of larval mortality in dry years.

The positive relationship between pond size and depth and maximum egg mass counts for both species probably was caused by the positive correlation between morphologic variables and pond hydroperiod. Skidds and Golet (2005) demonstrated that the relationship between pond depth and hydroperiod was strongest in glacial fluvial ponds; thus, it is not surprising that Wood Frog egg mass counts were higher in ponds located on glacial fluvial material, which tend to be relatively large and deep and to have long hydroperiods. Egg mass counts for both species were low in ponds on alluvium. This, too, is logical because alluvial ponds tend to be shallow and to have short hydroperiods (Skidds and Golet, 2005); in addition, reproductive success is likely to be low in these ponds because overbank flooding from nearby rivers may remove egg masses from the ponds and allow predatory fish access to them, at least in some years. Although not necessarily ideal habitat for pond-breeding amphibians, alluvial sites may still be of conservation interest for other habitat specialists (e.g., certain turtles, snakes, and invertebrates).

The amount of persistent nonwoody plant cover, which was positively correlated with Wood Frog breeding effort, was selected in both the within-pond and combined multivariate models. This likely reflects the importance of such vegetation for egg mass deposition and as a refuge for developing larvae (Seale, 1982; Formanowicz and Bobka, 1989; Egan and Paton, 2004). Unlike results reported by Egan and Paton (2004), within-pond vegetation structure was not significantly related to Spotted Salamander egg mass counts in our study, and other variables proved more important in multivariate model development. It is possible that vegetation structure has an effect on larval survival rates but that relationship was not examined in this study.

We found that canopy cover showed a relatively strong negative relationship to Wood Frog breeding effort. Skelly et al. (2002) demonstrated that the survival of Wood Frogs at breeding ponds was positively associated with increased canopy cover. By contrast, we found that Wood Frog egg mass counts peaked with moderate $(30-70 \%)$ canopy cover and then declined with increasing cover. Tree canopy cover was not related to Spotted Salamander egg mass numbers in this study.

The total area of upland forest within $1 \mathrm{~km}$ of the ponds was the only landscape-level characteristic consistently selected in Spotted Salamander models; this finding underscores the importance of upland habitat away from the breeding ponds (Gibbs, 1998; Porej et al., 2004; Homan et al. 2004; Hermann et al., 2005). Consistent with previous research (Egan and Paton, in press), our study showed that Wood Frog egg mass counts also were positively associated with the extent of upland forest near breeding ponds. Spotted Salamander and Wood Frog breeding effort tended to be greatest in ponds with over $50 \%$ forest cover within $1 \mathrm{~km}$ of those ponds, although there was not strong evidence of a threshold level (but see Homan et al., 2004). Guerry and Hunter (2002) found that the extent of upland forest cover within $1 \mathrm{~km}$ of breeding ponds positively influenced occupancy rates of breeding ponds for both species, whereas Porej et al. (2004) found that the occurrence of both species was positively associated with the amount of forest within $200 \mathrm{~m}$ of breeding ponds (referred to as the "core zone"). In addition, we found a negative relationship between the amount of residential development within $1 \mathrm{~km}$ of the ponds and Wood Frog egg mass counts, which suggests that Wood Frogs may be particularly sensitive to loss or fragmentation of upland habitat resulting from urban sprawl.

Habitat loss, degradation, and fragmentation are among the leading causes of population declines in pond-breeding amphibians (Hanski, 1998; Pough et al., 1998; Semlitsch, 2000a; Marsh and Trenham, 2001). Recent theoretical models suggest that even small, incremental habitat losses may cause catastrophic declines and extirpation of a species (Fahrig, 2001). Southern New England is experiencing rapid urbanization, not only near large metropolitan areas, but also in forested rural areas, such as southern Rhode Island. This results in loss of breeding and nonbreeding habitat, fewer contiguous 
patches of forest, and more potential dispersal barriers for migrating amphibians. One of the priorities in conservation planning should be to identify specific geographic areas that warrant protection because of their contribution to animal productivity and diversity (Pendergast et al., 1999). Knowledge of what constitutes high-quality habitat also is useful for setting reference conditions when investigating impacts to natural habitats in biological monitoring programs (Snodgrass et al., 2000). Both the quality and quantity of breeding ponds are important in maintaining viable amphibian populations (Semlitsch, 2000a,b), and protecting amphibian breeding habitat simultaneously benefits other organisms, including aquatic invertebrates, reptiles, and birds (Colburn, 2004). Our research suggests that within-pond factors such as hydroperiod, size, and depth may be useful in assessing the habitat suitability of existing ponds or in the design of proposed seasonal ponds. Conserving or creating seasonal ponds that hold water for moderate to long periods (mid-August to late November), will help to protect amphibian populations against complete reproductive failure caused by stochastic perturbations.

The precipitous decline in amphibian abundance with increasing road density and corresponding terrestrial habitat loss (Fahrig et al., 1995; deMaynadier and Hunter, 2000; Gibbs, 1998; Egan and Paton, in press) strongly suggests that protecting ponds independent of the adjacent habitats will do little to sustain populations of Wood Frogs and Spotted Salamanders. Our results also suggest that, before investing in conservation, creation, or enhancement of seasonal wetlands for amphibian breeding, it would be prudent to first consider the condition of the landscape surrounding the breeding pond. The models that we have developed suggest that forested uplands in particular are critical to pond-breeding amphibians.

Land use regulations in the northeastern United States are geared primarily toward protecting wetlands, including forested wetlands which may serve as nonbreeding habitat and as breeding sites for amphibians (Murphy and Golet, 1998). Currently, there is no regulatory mechanism for protecting extensive areas of upland forest that are critical habitat for these animals. Urbanization has probably already had a major impact on pond-breeding amphibian populations in the region. Steps need to be taken soon to protect landscapes that currently have relatively low road densities and large contiguous patches of forested upland if we hope to maintain viable populations of forest-dependent, pond-breeding amphibians into the future.
Because pond-breeding amphibians migrate so far from breeding ponds (Semlitsch, 2002; Smith and Green, 2005), it is unlikely that protection of required terrestrial habitat can be achieved through expansion of wetland regulations alone. For that reason, it is essential for ecologists and land managers to educate local conservation commissioners, town and regional planners, and private landowners on the importance of amphibian conservation and to provide specific recommendations on how to accomplish this in a proactive manner (e.g., Calhoun et al., 2005). Proactive habitat conservation might entail identifying all potential seasonal ponds within a town or watershed, ranking ponds in terms of their potential ability to support large or diverse amphibian communities based on within-pond and landscape characteristics, distinguishing protected ponds from unprotected ponds, and planning future development, as well as conservation land acquisition, from a town or watershed perspective rather than on a site-by-site basis. Such an approach can be implemented relatively quickly and would provide an effective supplement to land use regulation.

Acknowledgments.-The authors would like to thank H. Whiteman and two anonymous reviewers for their insightful comments on this manuscript. Access to study sites was granted by the Rhode Island Department of Environmental Management, the Audubon Society of Rhode Island, the Rhode Island Field Office of The Nature Conservancy, the Boy Scouts of Rhode Island, the Town of Richmond, and many generous private landowners throughout the Pawcatuck River watershed of Rhode Island. Funding for this project was provided by the Rhode Island Agricultural Experiment Station (RIAES), the U.S. Environmental Protection Agency, Region 1, and the Rhode Island Chapter of The Nature Conservancy. This is RIAES contribution number 5102.

\section{Literature Cited}

August, P. V. A., A. J. McCann, And C. L. Labash. 1995. Geographic Information Systems in Rhode Island. Natural Resource Fact Sheet No. 95-1. University of Rhode Island, Kingston.

BabbitT, K. J., AND G. W. TANner. 2000. Use of temporary wetlands by anurans in a hydrologically modified landscape. Wetlands 20:313-322.

Burnham, K. P., AND D. R. Anderson. 2002. Model Selection and Multimodel Inference: A Practical Information-Theoretic Approach. 2nd ed. SpringerVerlag, New York.

Calhoun, A. J. K., and M. W. Klemens. 2002. Best Development Practices for Conserving Pool-Breeding Amphibians in Residential and Commercial 
Developments in the Northeastern U.S. Metropolitan Conservation Alliance, Wildlife Conservation Society, MCA Technical Paper No. 5, Bronx, NY.

Calhoun, A. J. K., N. A. Miller, and M. W. Klemens. 2005. Conserving pool-breeding amphibians in human-dominated landscapes through local implementation of best development practices. Wetland Ecology and Management 13:291-304.

Canfield, R. 1941. Application of the line interception method in sampling range vegetation. Journal of Forestry 39:388-394.

Colburn, E. A. 2004. Vernal Pools: Natural History and Conservation. McDonald and Woodward Publishing Co. Blacksburg VA.

Crouch, W. B., III, AND P. W. C. Paton. 2000. Using egg mass counts to monitor Wood Frog populations. Wildlife Society Bulletin 28:895-901.

DeMaynadier, P. G., And M. L. Hunter. 1998. Effects of silvicultural edges on the distribution and abundance of amphibians in Maine. Conservation Biology 12:340-352.

— 1999. Forest canopy closure and juvenile emigration by pond-breeding amphibians in Maine. Journal of Wildlife Management 63:441450.

2000. Road effects on amphibian movements in a forested landscape. Natural Areas Journal 20:56-65.

Egan, R. S., And P. W. C. Paton. 2004. Within-pond parameters affecting oviposition by Wood Frogs and Spotted Salamanders. Wetlands 24:1-13.

—. In press. Multiple scale habitat characteristics of pond-breeding amphibians across a rural-urban gradient. In R. E. Jung and J. C. Mitchell (eds.), Urban Herpetology. Herpetological Conservation. Volume 3, Society for the Study of Reptiles and Amphibians, Salt Lake City UT.

FAHRIG, L. 2001. How much habitat is enough? Biological Conservation 100:65-74.

Fahrig, L., J. H. Pedlar, S. E. Pope, P. D. Taylor, and J. F. WEgner. 1995. Effect of road traffic on amphibian density. Biological Conservation 73:177-182.

FLINT, R. F. 1971. Glacial and Quaternary Geology. John Wiley and Sons, New York.

FormanowicZ, D. R., AND M. S. BOBKA. 1989. Predation risk and microhabitat preference: an experimental study of the behavioral responses of prey and predator. American Midland Naturalist 121: 379-386.

GIBBS, J. P. 1998. Distribution of woodland amphibians along a forest fragmentation gradient. Landscape Ecology 13:263-268.

- 2000. Wetland loss and biodiversity conservation. Conservation Biology 14:314-317.

Guerry, A. D., And M. L. Hunter Jr. 2002. Amphibian distributions in a landscape of forests and agriculture: an examination of landscape composition and configuration. Conservation Biology 16:745-754.

HANSKI, I. 1998. Metapopulation dynamics. Nature 396:41-49.

Hermann, H. L., K. J. Babbitt, M. J. Baber, and R. G. Congalton. 2005. Effects of landscape characteristics on amphibian distribution in a forest-dominated landscape. Biological Conservation 123: 139-149.
Homan, R. N., B. S. Windmiller, And J. M. Reed. 2004. Critical thresholds associated with habitat loss for two vernal pool-breeding amphibians. Ecological Applications 14:1547-1553.

Klemens, M. W. 1993. Amphibians and Reptiles of Connecticut and Adjacent Regions. State Geological and Natural History Survey of Connecticut Bulletin No. 112, Hartford, CT.

Koloszvary, M. B., and R. K. Swihart. 1999. Habitat fragmentation and the distribution of amphibians, patch and landscape correlates in farmland. Canadian Journal of Zoology 77:1288-1299.

LAAN, R., AND B. VerboOm. 1990. Effects of pond size and isolation on amphibian communities. Biological Conservation 54:251-262.

Lehtinen, R. M., S. M. Galatowitsch, and J. R. Tester. 1999. Consequences of habitat loss and fragmentation for wetland amphibian assemblages. Wetlands 19:1-12.

Marsh, D. M., And P. C. Trenham. 2001. Metapopulation dynamics and amphibian conservation. Conservation Biology 15:40-49.

Murphy, M. C., AND F. C. Golet. 1998. Development of Revisions to the State of Rhode Island's Freshwater Wetland Regulations. Final report prepared for Rhode Island Department of Environmental Management, Office of Water Resources. University of Rhode Island Department of Natural Resources Science, Kingston.

Paton, P. W. C., AND W. B. Crouch. 2002. Using breeding phenology of pond-breeding amphibians to develop conservation strategies. Conservation Biology 18:194-204.

Pendergast, J. R., R. M. Quinn, And J. H. Lawton. 1999. The gaps between theory and practice in selecting nature reserves. Conservation Biology 13:484-492.

Petranka, J. W. 1998. Salamanders of the United States and Canada. Smithsonian Institution Press, Washington DC.

Pope, S. E., L. Fahrig, and H. G. Merriam. 2000. Landscape complementation and metapopulation effects on Leopard Frog populations. Ecology 81:2498-2508.

Porej, D., M. Micacchion, and T. E. Hetherington. 2004. Core terrestrial habitat for conservation of local populations of salamanders and Wood Frogs in agricultural landscapes. Biological Conservation 120:399-409.

Pough, F. H., R. M. Andrews, J. E. Cadle, M. L. Crump, A. H. SavitzKy, and K. D. Wells. 1998. Herpetology. Prentice-Hall, Inc, Upper Saddle River NJ.

QuinN, A. W. 1973. Rhode Island Geology for the NonGeologist. Rhode Island Department of Natural Resources, Providence.

ReCtOR, D. D. 1981. Soil Survey of Rhode Island. U.S. Department of Agriculture, Soil Conservation Service, West Warwick, RI.

Rosenblatt, A. E. 2000. Hydric Soil Patterns in Riparian Corridors of the Glaciated Northeast: Groundtruthing the Soil Survey Geographic Data Base (SSURGO). Unpubl. master's thesis, University of Rhode Island, Kingston.

Rothermel, B. B., AND R. D. Semlitsch. 2002. An experimental investigation of landscape resistance of forest versus old-field habitats to emigrating 
juvenile amphibians. Conservation Biology 16:1324 $-1332$.

Schafer, J. P., And J. H. Hartshorn. 1965. The Quaternary of New England. In H. E. Wright JR. and D. G. Frey (eds.), The Quaternary of the United States, pp. 113-125. Princeton University Press, Princeton, NJ.

SEALE, D. B. 1982. Physical factors influencing oviposition by the Wood Frog, Rana sylvatica, in Pennsylvania. Copeia 1982:627-635.

Semlitsch, R. D. 2000a. Principles for management of aquatic-breeding amphibians. Journal of Wildlife Management 64:615-631.

- 2000b. Size does matter: the value of small isolated wetlands. National Wetlands Newsletter 22:5-6, 13 .

- 2002. Critical elements for biologically based recovery plans of aquatic-breeding amphibians. Conservation Biology 16:619-629.

SINSCH, U. 1992. Structure and dynamic of a Natterjack Toad metapopulation (Bufo calamita). Oecologia 90:489-499.

Sjogren-Gulve, P. 1994. Distribution and extinction patterns within a northern metapopulation of the pond frog, Rana lessonae. Ecology 75:1357-1367.

SKELly, D. K., AND J. Golon. 2003. Digestive assimilation in tadpoles: the role of forest canopy cover. Herpetologica 59:37-42.
Skelly, D. K., L. K. FreidenburG, and J. M. Kiesecker. 2002. Forest canopy and the performance of larval amphibians. Ecology 83:983-992.

SKIDDS, D. E., AND F. C. Golet. 2005. Estimating hydroperiod suitability for breeding amphibians in southern Rhode Island seasonal forest ponds. Wetlands Ecology and Management 13:349-366.

Smith, M. A., AND D. M. GreEn. 2005. Dispersal and the metapopulation paradigm in amphibian ecology and conservation: are all amphibian populations metapopulations? Ecography 28:110-128.

SNODGRASS, J. W., M. J. KOMOROSKI, A. J. BRYAN JR., AND J. BURGER. 2000. Relationships among isolated wetland size, hydroperiod, and amphibian species richness: implications for wetland regulations. Conservation Biology 14:414-419.

UnderwOod, A. J. 1997. Experiments in Ecology: Their Logical Design and Interpretation Using Analysis of Variance. Cambridge University Press, Cambridge, UK.

Vos, C. C., AND J. P. Chardon. 1998. Effects of habitat fragmentation and road density on the distribution of the Moor Frog, Rana arvalis. Journal of Applied Ecology 35:44-56.

Wilbur, H. M. 1980. Complex life cycles. Annual Review of Ecology and Systematics 11:67-93.

Accepted: 4 April 2007. 